\title{
Study on Changes of Textural and Biochemical Properties of Tuna during Ultra-Low Temperature Storage
}

\author{
Yu-ying PAN ${ }^{1}$, Xiao-hua QIU ${ }^{2} \&$ Jin-sheng YANG ${ }^{1}$ \\ ${ }^{1}$ Zhejiang Ocean University, Zhoushan 316022, Zhejiang, China \\ ${ }^{2}$ Zhou Shan Tourism and Health College, Zhoushan 316000, Zhejiang, China \\ Correspondence: Jin-sheng YANG, Zhejiang Ocean University, Zhoushan 316022, Zhejiang, China. E-mail: \\ yanhjinsheng@163.com
}

$\begin{array}{lc}\text { Received: February15, } 2016 & \text { Accepted: February26, } 2016 \quad \text { Online Published: April 25, } 2016 \\ \text { doi:10.5539/enrr.v6n2p51 } & \text { URL: http://dx.doi.org/10.5539/enrr.v6n2p51 }\end{array}$

\begin{abstract}
The effect of TPA and biochemical properties of Yellow Tuna during frozen storage at different temperatures $\left(-18^{\circ} \mathrm{C},-25^{\circ} \mathrm{C},-35^{\circ} \mathrm{C},-45^{\circ} \mathrm{C},-55^{\circ} \mathrm{C},-65^{\circ} \mathrm{C}\right)$ were studied by measuring the textural characteristics (the hardness, Springiness) salt-solubility of myofibrillar proteins, $\mathrm{Ca}^{2+}$ ATPase activities. The results indicated that the hardness, springiness, actomyosin salt-solubility, $\mathrm{Ca}^{2+}$ ATPase activities decreased during the process of frozen storage. Meanwhile, the frozen stored temperature showed great effect on the freezing denaturation of protein $(\mathrm{P}<0.05)$. For the same longer of the storage time, the lower frozen temperature, the less extent of freeze denaturation; Stored in $-18^{\circ} \mathrm{C}$ for three months, the content of Salt soluble protein reduced to zero; Stored in $-25^{\circ} \mathrm{C}$ for 120 days, the content of salt soluble protein also reduced to zero; But stored in $-55^{\circ} \mathrm{C}$ and $-65^{\circ} \mathrm{C}$, the change is very little. $\mathrm{Ca}^{2+} \mathrm{ATPase}$ activities also reduced to zero after stored in $-18^{\circ} \mathrm{C}$ and $-25^{\circ} \mathrm{C}$ for three months. But stored in $-55^{\circ} \mathrm{C}$ and $-65^{\circ} \mathrm{C}$, there is no obvious change. Moreover, there is a Positive relationship between the change of texture profile and the content of Salt soluble protein, the lower the storage temperature, the less of the change of texture profile. Therefore, when it is stored in $-55^{\circ} \mathrm{C}$, the quality of Yellow Tuna can be maintained to the maximum extent within six months.
\end{abstract}

Keywords: tuna, ultra-lowtemperature, texture profile analysis (TPA), biochemical properties

\section{Introduction}

Yellowfin tuna (Thunnus albacares) are pelagic fish ,usually living in tropical and temperature waters. Its main habitat is usually in the depth of 50 250 $\mathrm{m}$, and the depth depends on the season and the different areas of sea level. Tuna meat is tender, tasty, high protein. Thus it has high nutritional value. However, the tuna meat preservation conditions are harsh. In the process of refrigeration, the good quality of tuna meat will lose. In order to make the tuna the same color and texture, tuna meat is frozen in the low temperature of $-80^{\circ} \mathrm{C}$. But meanwhile it consumes too much energy.

The texture, salt-soluble protein content, $\mathrm{Ca}^{2+} \mathrm{ATP}$ activity, WHC values of yellowfin tuna back muscles were studied at different frozen storage temperatures and finding the best frozen temperature was $-55^{\circ} \mathrm{C}$, which can guarantee the quality and save more energy. In this study, it is provided some theoretical basis for controlling tuna meat quality and transport.

\section{Materials and Methods}

\subsection{Materials}

Tuna was donated by a local tuna factory (Yuanyang, Ningbo); $\mathrm{Ca}^{2+}$ ATPase kit was bought by Reagent Company (Jiancheng, Nanjing); All other chemicals were analytical grade products.

\subsection{Fish Sample and Storage Condition}

Take four Yellowfin tunas of the same size and divide each of them into four parts, then divide the back muscles of the each part into the shape of trapezoid. Take $500 \mathrm{~g}$ of the back muscles of the tuna, and then pack it in sealing. Then frozen it for 6 months in different temperatures $\left(-18^{\circ} \mathrm{C},-25^{\circ} \mathrm{C},-35^{\circ} \mathrm{C},-45^{\circ} \mathrm{C},-55^{\circ} \mathrm{C}\right)$. It was measured every $15 \mathrm{~d}$ before test it was thawed at $4^{\circ} \mathrm{C}$ in order to eliminate the influence of low temperature. 


\subsection{Determination of Texture}

Take the TMS-Pro material analyzer under the measuring mode of Texture Profile Analysis (TPA) the size of whose probe is $\mathrm{P} / 20$. The speed of the probe before the test when testing are both $1 \mathrm{~mm} / \mathrm{s}$. The ratio of the compression is $60 \%$, trigger type is automatic $1 \mathrm{~N}$. The reciprocating motion is done by two times, test three times of each sample by the quality and structure analyzer. The sample is the muscles of the back of the tuna, of which the size is $3 \mathrm{~cm} \times 3 \mathrm{~cm} \times 3 \mathrm{~cm}$. the hardness, Springiness, Cohesiveness as the studied object.

\subsection{The Extraction of the Actomyosin Salt-Solubility}

Get $5 \mathrm{~g}$ fish, adding 10 times of the amount of Tris-HCI buffer (pH7.05), meanwhile homogenize three times at speed of $20000 \mathrm{rpm}$, each time within $30 \mathrm{~s}$, then centrifuge $15 \mathrm{~min}$ with $10000 \mathrm{r} / \mathrm{min}$ under low temperature $\left(4^{\circ} \mathrm{C}\right)$. After that discard the supernatant and precipitate with cold $0.1 \mathrm{MKCl} 50 \mathrm{mM}$ Tris- $\mathrm{HCl}(\mathrm{pH}=7.05)$ anddissolve in buffer solution. After fully homogenized at $4^{\circ} \mathrm{C}$ to extract salt-soluble protein $1 \mathrm{~h}$, centrifuge at $9000 \mathrm{r} / \mathrm{min}$ under $10 \mathrm{~min}$, and supernatant is the experimental actomyosin salt-solubility protein solution. actomyosin salt-solubility quantification: Coomassie brilliant blue method.

\section{$2.5 \mathrm{Ca}^{2+}$ ATPase Values}

Using Nanjing Jiancheng ATP kit

Operating procedures:

1) Enzymatic reactions: the instructions 1001 added to the sample and reagent mixing, $37^{\circ} \mathrm{C}$ accurate for 10 minutes;

2) Plumed R7,3500 rev / min, centrifuged for 10 minutes and got the supernatant

3) Phosphorus compounds was added into the supernatantat room temperature for 2 minutes and plumed terminator

4) At $636 \mathrm{~nm}$ wavelength, $1 \mathrm{~cm}$ light path, colorimetric

\subsection{Statistical Analysis}

Data are expressed as mean values $(n=3)$ accompanied by the standard errors of means. Data from the different composition and quality parameters were subjected to one-way ANOVA $(\mathrm{p}<0.05)$ by employing an SPSS software (version 17.0). Comparison of means after the ANOVA test was performed using the Duncan's multiple range test $(\mathrm{p}<0.05)$.

\section{Results and Discussion}

\subsection{Texture Profile Analysis}

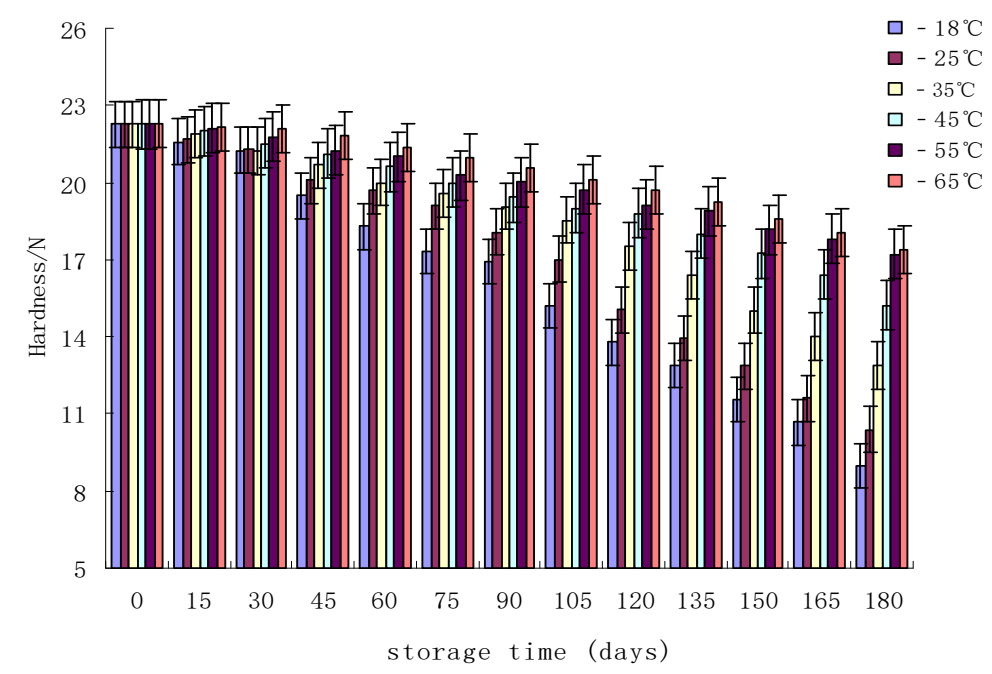

Figure 1. Effect of different storage temperatures on the Hardness of Tuna 
Texture and appearance of food, flavor, nutrition together constitute the four quality factors of the food (Kristiansen et al., 2007). Hardness showed the tactile sense of human body soft or hard, the power can make food to a certain deformation. we can draw the conclusion from the figure, in the frozen process, the longer the frozen storage time, the smaller the hardness gradually became, but at different temperatures, the hardness changes $(\mathrm{p}<0.05)$ significantly. When frozen at $-18^{\circ} \mathrm{C}$, the hardness of tuna changed maximum and frozen for six months, the hardness decreased from the beginning of $22.7 \mathrm{~N}$ to $8.98 \mathrm{~N}$ and dropped $61 \% ;-25^{\circ} \mathrm{C}$ frozen, the hardness dropped $46.5 \% ;-35^{\circ} \mathrm{C}$ frozen, the hardness dropped $26.9 \% ;-45^{\circ} \mathrm{C}$ the hardness dropped $23.1 \% ;-55^{\circ} \mathrm{C}$ the hardness dropped $17.1 \% .-65^{\circ} \mathrm{C}$ the hardness dropped $16.5 \%$. The change of hardness related to the decrease of salt-soluble protein content and enzyme activity. On the one hand, during the frozen because ATP activity decreased fast, leading to serious action protein denaturation. On the other hand, due to the process of frozen, free water in tuna meat frozen into ice crystals, formed mechanical damage to the muscle cells, changed the protein three-dimensional structure, resulted in the decrease of muscle hardness (Katsunori et al., 2009; CHOW et al., 1985).

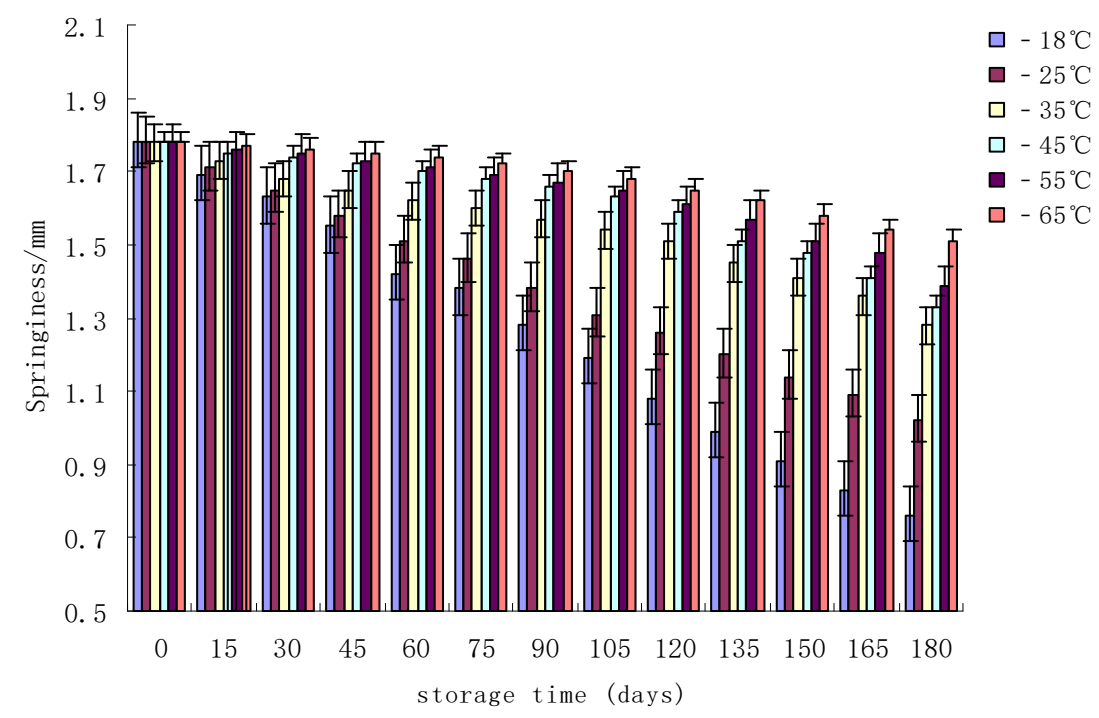

Figure 2. Effect of different storage temperatures on the Springiness of Tuna

Springiness reflected the recovery degree of deformation after eliminating force in external force. From the chart above, in the frozen process, when frozen at $-18^{\circ} \mathrm{C}$, the Springiness change of tuna was maximum and frozen for six months, the Springiness decreased $57.8 \% ;-25^{\circ} \mathrm{C}$ the Springiness decreased $46.5 \% ;-35^{\circ} \mathrm{C}$ frozen, the Springiness decreased $26.9 \% ;-45^{\circ} \mathrm{C}$ the Springiness decreased $23.1 \% ;-55^{\circ} \mathrm{C}$ the Springiness decreased $17.1 \%$; $-65^{\circ} \mathrm{C}$ the Springiness decreased $16.8 \%$. The change of Springiness related to the degree of protein denaturation (WOOJ et al., 2007; Sato et al., 1986; Luis, 1999).

\subsection{Actomyosin Salt-Solubility Analysis}

We can draw the conclusion from the Figure 3 that refrigerating at different temperatures, with frozen time increasing, the salt-soluble protein content showed a downward trend. The lower frozen storage temperature, the more slowly salt-soluble protein content decreased. Under the temperature of $-18^{\circ} \mathrm{C}$, the change in former $45 d$ is great. It decreased from $47.5 \mathrm{mg} / \mathrm{g}$ to $15.2 \mathrm{mg} / \mathrm{g}$. After 90 days, it decreased to 0 ; under the temperature of $-25^{\circ} \mathrm{C}$, the salt-soluble myofibril protein content changed rapidly from $30 d$ to $75 d$, in the 120 th days, it closes to 0 ; under the temperature $-35^{\circ} \mathrm{C}$, it changed rapidly from $120 d$; under the temperature $-45^{\circ} \mathrm{C}$, it changed rapidly from $135 d$; under the temperature $-55^{\circ} \mathrm{C}$ and $-65^{\circ} \mathrm{C}$, it changed small after 6 months.

Features function of protein is determined by act myosin salt-soluble protein. After protein denatured, the act myosin salt-soluble protein decreased and the content of salt-soluble protein also decreased. Therefore, the content of salt-soluble protein, in a certain extent, reflected the penetration of proteins (Somjit et al., 2005). 


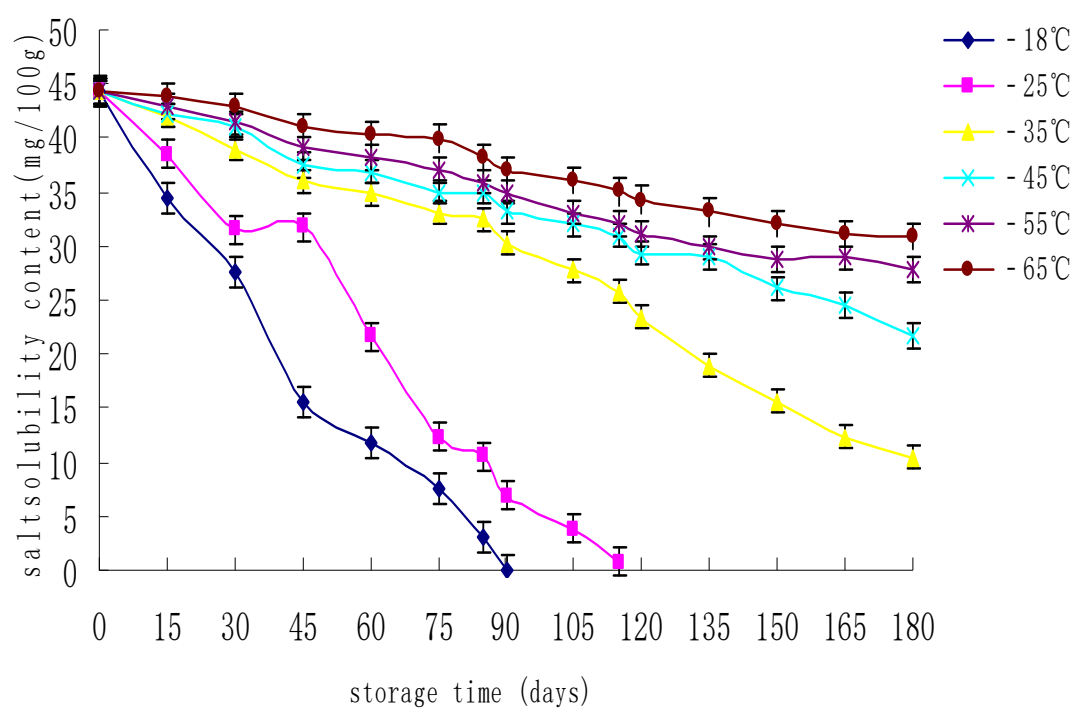

Figure 3. Effect of different storage temperatures on the salt-solubility of Tuna

\subsection{Activity of $\mathrm{Ca}^{2+}$ ATPase Analysis}

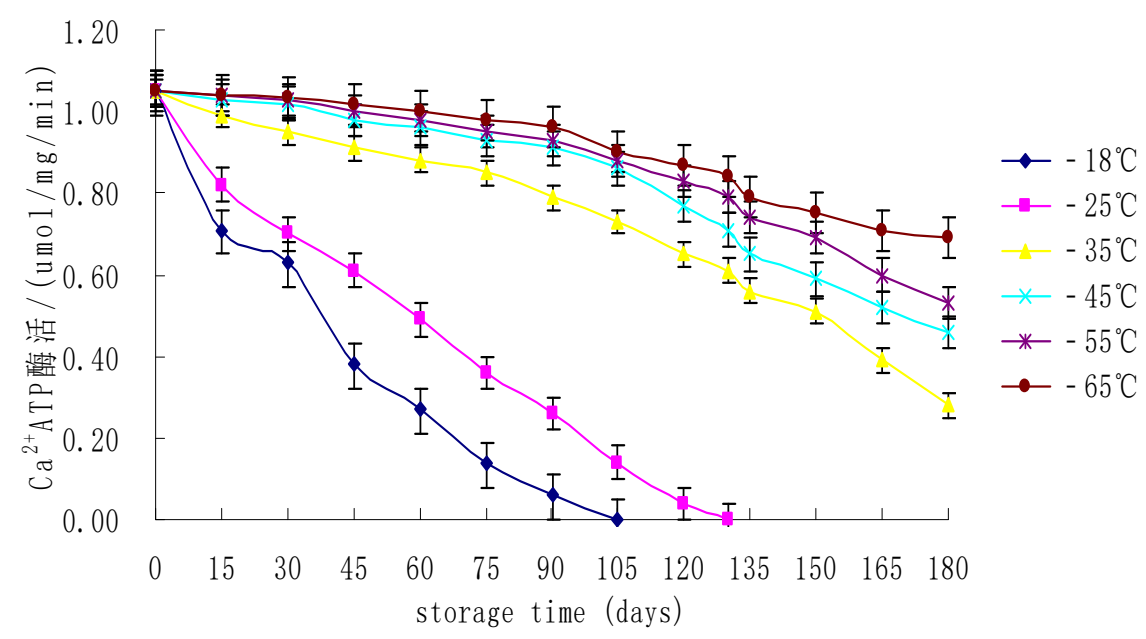

Figure 4. Effect of different storage temperatures on the activity of $\mathrm{Ca}^{2+}$ ATPase

We can draw the conclusion from the Figure 4 that under the temperature of $-18^{\circ} \mathrm{C},-25^{\circ} \mathrm{C},-35^{\circ} \mathrm{C},-45^{\circ} \mathrm{C}$, it changed obvious, however, $-55^{\circ} \mathrm{C}$ and $-65^{\circ} \mathrm{C}$ it changed small. $\mathrm{Ca}^{2+} \mathrm{ATP}$ activity declined with frozen storage time. The lower temperature, the better ATP activity maintained the higher. Activity of $\mathrm{Ca}^{2+}$-ATPase Was directly related to the degree of actomyosin denaturation, thus, determined the $\mathrm{Ca}^{2+}$-ATP activity had the significance in study the Protein Traits as well as judged the degree of act myosin denaturation (Hatful et al., 2012). On the one hand, Some people thought the reason of decrease the $\mathrm{Ca}^{2+}$-ATPase's activity was caused by the configuration change in the myosin's globular head. On the other hand, interactions rearrangement in protein was also been thought to cause the $\mathrm{Ca}^{2+}$ ATP activity decreased (Li et al., 2009).

\subsection{Water-Holding Capacity Analysis}

Water is one of the most important ingredients in meat and meat products. The water of muscles is about $75 \%$ and it has relation with the structure, tenderness, flavor, color, processing characteristics of meat products. Water holding capacity will directly affect the meat's quality and economic benefits. 


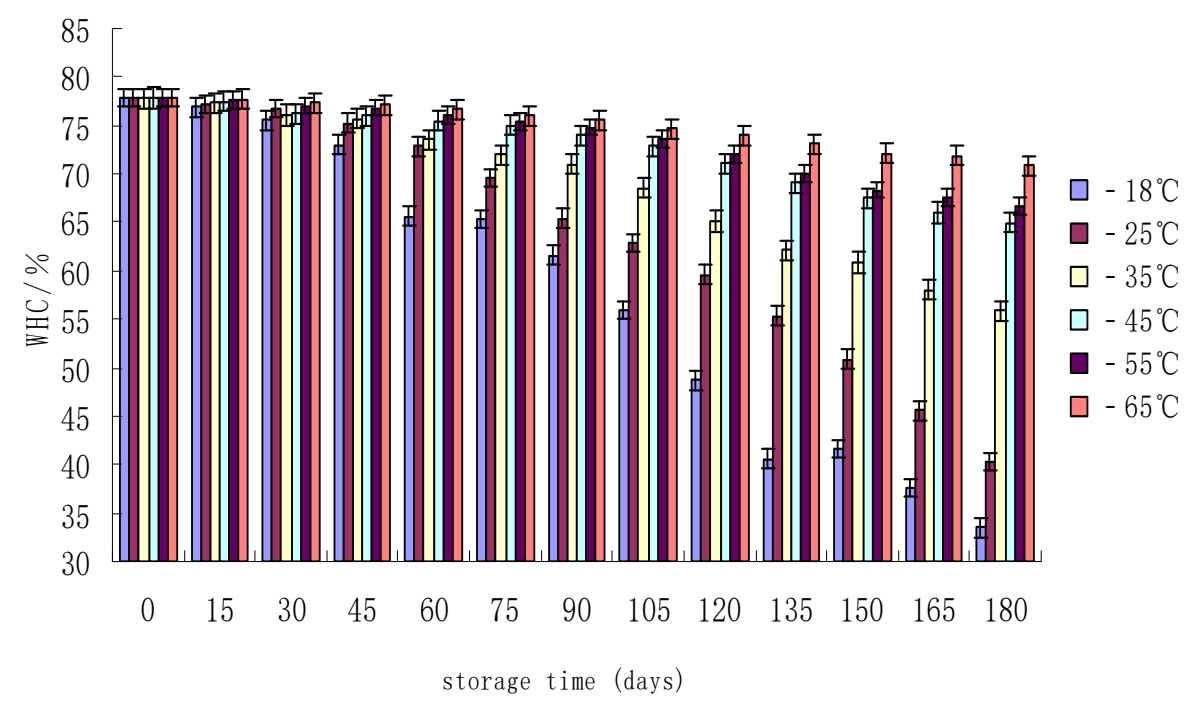

Figure 5. Effect of different storage temperature on the WHC of Tuna

We can draw the conclusion from the figure 4 that under the temperature of $-18^{\circ} \mathrm{C}$. WHC decreased to $35 \%$, $-25^{\circ} \mathrm{C}$ it decreased to $43 \%,-35^{\circ} \mathrm{C}$ it decreased to $27 \%,-45^{\circ} \mathrm{C}$ it decreased to $23 \%,-55^{\circ} \mathrm{C}$ it decreased to $17 \%$, $-65^{\circ} \mathrm{C}$ it decreased to $16 \%$. WHC decreased because the hydrophobic bonding of protein was damaged. Moleculeof water ofaffinity protein became intofree water, Meanwhile the combination chance of Amino acid was increased and the degeneration of protein condensed during frozenstorage (Bengkulu et al., 2003).

\section{Summary}

Different frozen temperatures significantly impacted on the texture and biochemical characteristics of tuna back muscle. With frozen time increasing, hardness, springiness of tuna muscle decreased, the higher frozen storage temperature, the worse texture. With frozen time increasing, the content of act myosin salt-soluble protein, and $\mathrm{Ca}^{2+}$ ATP activity showed a downward trend. The higher frozen temperature is, and the higher degree of protein penetration.

Change of texture related to protein denaturation, but the function features of protein is determined by actomyosin salt-soluble protein, thus change of texture related to the content decreasing of actomyosin salt-soluble protein. Under the temperatures of $-55^{\circ} \mathrm{C}$, the change of the content of actomyosin salt-soluble was not obvious and the change of texture was also small. Thus refrigerating in $-55^{\circ} \mathrm{C}$ could keep the best quality of tuna during these six months.

\section{References}

Badii, F., \& Howell, N. K. (2002a). A comparison of biochemical changes in cod (Gadus morhua) and haddock (Melanogrammus aeglefinus) fillets during frozen storage. J. Sci. Food Agric., 82, 87-97. http://dx.doi.org/ $10.1002 /$ jsfa. 998

Badii, F., \& Howell, N. K. (2002b). Changes in the texture and structure of cod and haddock fillets during frozen storage. Food Hydrocolloids, 16, 313-319. http://dx.doi.org/10.1016/S0268-005X(01)00104-7

Godiksen, H., \& Jessen, F. (2001). Sarcoplasmic reticulum $\mathrm{Ca}^{2+}$-ATPase activity in cod (Gadusmorhua) muscle measured in crude homogenates. J. Food Biochem, 25, 343-358.

Godiksen, H., Hyldig, G., \& Jessen, F. (2003). Sarcoplasmic reticulum $\mathrm{Ca}^{2+}$-ATPase and cytochrome oxidase as indicators of frozen storage in cod (Gadus morhua). J. Food Sci., 68, 2579-2585. http://dx.doi.org/10. 1111/j.1365-2621.2003.tb07064.x

Kristinsson, H. G., Ludlow, N., Balaban, M. O., Otwell, W. S., \& Welt, B. A. (2011). Muscle Quality of Yellowfin Tuna (Thinness albacores) Steaks After treatment with Carbon Monoxide Gases and Filtered Wood Smoke. J Aquat Food Prod T, 15, 49-67.

Leelapongwattana, K., Benjakul, S., Visessanguan, W., \& Howell, N. K. (2005). Physicochemical and biochemical changes during frozen storage of minced flesh of lizardfish (Saurida micropectoralis). Food Chemistry, 90(1), 141-150. 
Nielsen, J., \& Jessen, F. (2007). Quality of frozen fish in Handbook of Meat, Poultry and Seafood Quality. In L. M. L. Nollet (Ed.) Blackwell Publishing: Iowa (pp. 577-586). http://dx.doi.org/10.1002/978047027782 9.ch44

Ruiz-Capillas, C., \& Moral, A. (2001a). Correlation between biochemical and sensory quality indices in hake stored in ice. Food Res Int., 34, 441-447. http://dx.doi.org/10.1016/S0963-9969(00)00189-7

Saguy, I., \& Karel, M. (1980). Modeling of quality deterioration during food processing and storage. Food Technol., 34, 78-85.

Sikorski, Z. E. (1978). Protein changes in muscle foods due to freezing and frozen storage. Int. J. Refrig., 1, 173180. http://dx.doi.org/10.1016/0140-7007(78)90094-4

Steen, C., \& Lambelet, P. (1997). Texture changes in frozen cod mince measured by low-field nuclear magnetic resonance spectroscopy. J. Sci. Food Agric., 75, 268-272. http://dx.doi.org/10.1002/(SICI)1097-0010 (199710)75:2\%3C268::AID-JSFA881\%3E3.3.CO;2-F

Tironi, V. A., \& Toma' s, M. C. (2007). Lipid and protein deterioration during the chilled storage of sea salmon (Pseudopercis semifasciata). J Sci Food Agr, 87(12), 2239-2246. http://dx.doi.org/10.1002/jsfa.2949

Ueki, N., \& Ochiai, Y. (2004). Primary structure and thermostability of bigeye tuna myoglobin in relation of those of other scombridae fish. Fisheries Sci., 70, 875-884. http://dx.doi.org/10.1111/j.1444-2906.2004. 00882.x

Uresti, R., Téllez-Luis, S., Ramírez, J., \& Vázquez, M. (2004). Use of diary proteins and microbial transglutaminase to obtain low-salt fish products from filleting waste from silver carp (Hypophthalmichthys molitrix). Food Chem., 86, 257-262.

Visessanguan, W., Chutima, T., \& Munehiko, T. (2005). Effect of frozen storage on chemical and gel-forming properties of fish commonly used for surimi production in Thailand. Food Hydrocol., 19, 197-207.

Watanabe, H., Yamanaka, H., \& Yamanakawa, H. (1992). Post mortem biochemical changes in the muscle of disk abalone during storage. Nippon Suisan Gak., 58, 2081-2088. http://dx.doi.org/10.2331/suisan.58.2081

Zhu, S., Ramamwamy, H. S., \& Simpson, B. K. (2004). Effect of high-pressure versus conventional thawing on color, drip loss and texture of Atlantic salmon frozen by different methods. Food Sci. Technol-Leb., 37, 291-299.

\section{Copyrights}

Copyright for this article is retained by the author(s), with first publication rights granted to the journal.

This is an open-access article distributed under the terms and conditions of the Creative Commons Attribution license (http://creativecommons.org/licenses/by/3.0/). 